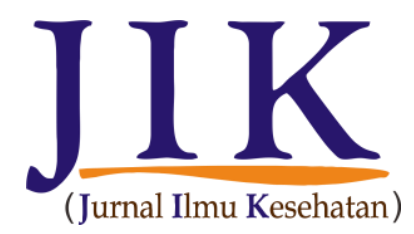

Jurnal Ilmu Kesehatan

Online ISSN: 2597-8594

Print ISSN: 2580-930X

Jurnal homepage: https://jik.stikesalifah.ac.id

\title{
Pengaruh Endorphine Massage Terhadap Tingkat Kecemasan Ibu Primigravida
}

\author{
Diana Arianti ${ }^{1}$, Ledia Restipa ${ }^{2}$ \\ ${ }^{1,2}$ STIKes Alifah Padang, Jln. Khatib Sulaiman No.52 B, Padanga, 25000, Indonesia \\ Email: ${ }^{1}$ dianaarianti84@gmail.com, ${ }^{2}$ lediarestipa86@gmail.com
}

\begin{abstract}
Abstrak
Kecemasan yang terjadi pada kehamilan adalah kekhawatiran dan ketakutan.Wanita yang mengalami kecemasan menunjukkan penurunan pelepasan oksitosin dan peningkatan adrenlin yang mengakibatkan kontraksi pada uterus secara tidak teratur dan tidak efektif. Ansietas juga mengurangi pelepasan endorfin dan wanita hamil mengalami lebih banyak rasa sakit 3-5 stimulasi sistem simpatis karena rasa sakit dan stres (Zumrut 2018). Angka kematian ibu di Indonesia masih tertinggi di ASEAN yaitu 214 per 100.000 kelahiran yang belum sesuai dengan target gloal SDGs (Suitainable Development Goals) (WHO 2014). Tujuan penelitian ini untuk mempelajari dan mengidentifikasi pengaruh endorphin masssage terhadap tingkat kecemasan pada ibu hamil pada kala 1 di bidan praktek swasta yang ada diwilayah kerja Puskesmas Tunggul Hitam Kota Padang Tahun 2019. Jenis penelitian ini kuatitatif dengan Quasi Eksperiment dengan rancangan two group pretest-Posttest Design. Jumlah sampel penelitian 30 responden dengsan teknik pengambilan sampel secara purposive sampling. Penelitian ini dilaksanakan bulan Maret-Agustus 2019 di bidan praktek swasta yang ada diwilayah kerja Puskesmas Dadok Tunggul Hitam Kota Padang. Hasil penelitian memperoleh nilai rata-rata tingkat kecemasan pada kelompok eksperimen adalah 0,667, sedangkan rata-rata tingkat kecemasan pada kelompok kontrol adalah 0,267. Berdasarkan uji t-test diperoleh nilai p value 0,003 $(p<0,05)$. Artinya terdapat tingkat kecemasan yang bermakna pada kelompok eksperimen sebelum dan sesudah diberi massage endorphine. Berdasarkan uji t-test diperoleh nilai $p$ value 0,041 ( $p<0,05)$. Kesimpulan dari penelitian ini terdapat tingkat kecemasan yang bermakna pada kelompok kontrol sebelum dan sesudah tanpa diberi endorphine massage.
\end{abstract}

Kata kunci: Kecemasan, Kehamilan, Endorphine masssage

\section{Effect of Endorphine Massage on The Anxiety Level of Primigravida Abstract}

Anxiety that occurs in pregnancy is worry and fear. Women who experience anxiety showed a decrease in the release of oxytocin and increase adrenlin which resulted in a contraction in the uterus is not regular and not effective. Anxiety also reduces the release of endorphins and pregnant women experience more a lot of pain 3-5 stimulation of the sympathetic system due to pain and stress (Zumrut 2018). Figures death of mother in Indonesia is the highest in ASEAN that is 214 per 100,000 births were not in accordance with the target Gloal SDGs ( Suitainab le Development Goals) (WHO 2014). . The purpose of this research is to study and identify the effects of endorphin masssage to the level of anxiety in the mother was pregnant at the time 1 in midwifery practice privately that exist in the region work Puskesmas stumps Black Padang Year 2019. The type of research is quantitative with Quasi Experiment with the design of two group pretest-posttest design. Total sample study 30 respondents Dengsan technique of taking samples by purposive sampling . Research is carried out in March - August 2019 in midwifery practice privately that exist in the region work Puskesmas Dadok stumps Black Padang. The results obtained an average level of anxiety in the experimental group was 0.667, while the average level of anxiety in the control group was 0.267. Based on the t-test that obtained a value of $p$ value $0.003(p<0.05)$. This means that there is a significant level of anxiety in the experimental group before and after being given endorphine massage. Based on the t-test that has been done, $p$ value of 0.041 ( $p<0.05)$. The conclusion from this study there is a significant level of anxiety in the control group before and after without being given an endorphine massage.

Keywords: Anxiety, Pregnancy, Endorphine masssage 


\section{PENDAHULUAN}

Kecemasan pada ibu hamil merupakan permsalahan psikologis dan reaksi emosional, rasa kekhawatiran, perkembangan janin, keberlangungan kehamilan, persalinan, setelah persalinan dan persiapan peran baru menjadi ibu ((Göbel et al. 2018). Kecemasan yang berlanjut saat menghadapi persalinan akan berakibat sulitnya dan lamanya persalinan serta beresiko untuk kematian ibu dan janinnya. Prevalensi kecemasan dan depresi pada negara maju sekitar 7-20\% dan negara berkembang sekitar 20\% (Biaggi A. C. P. P. 2015).

Menurut World Health Organitation (WHO) ibu yang meninggal saat bersalin sejumlah 358.000 (99\%) pertahun. Pada negara berkembang angka kematian ibu merupakan peringkat tertinggi dengan jumlah 290 kematian ibu per 100.000, tahun 2015 angka kematian ibu didunia yaitu 303.000 menurun sekitar $44 \%$ dibandingkan dengan tahun 2010 sebanyak 536.000, negara Amerika Serikat yaitu 9300 jiwa, afrika utara 179.000 jiwa dan Asia Tenggara 16.000 jiwa, angka kematian ibu di Indonesia masih tertinggi di ASEAN yaitu 214 per 100.000 kelahiran yang belum sesuai dengan target global SDGs (Suitainable Development Goals) (WHO 2014). Cakupan ibu bersalin di Indonesia pada tahun 2015 sebanyak 5.007 .191 bersalin. Sedangkan seluruh populasi di pulau Sumatera terdapat $679.765 \mathrm{ibu}$ amil yang mengalami kecemasan dalam menghadapi persalinan 255.873 orang $(52,3 \%)$ (Departemen Kesehatan RI 2015).

Pada kehamilan primigravida mengalami proses persalinan lebih lama daripada multigravida. Hal ini menyebabkan primigravida merasa lebih letih, persepsi nyeri meningkat dan rasa was-was meningkatkan rasa nyeri. Kondisi tersebut dapat mengakibatkan kontraksi uterus tidak efektif yang memicukan terjadinya distosia (kegagalan kemajuan persalinan), karena pembukaan serviks juga terjadi penipisan serviks dan kelamaan his yang menyebabkan partus lama (Wiknjosastro 2010) . Rasa nyeri pada persalinan merupakan hal yang wajar dan alamiah. Tetapi apabila tidak diatasi dengan akan menimbulkan masalah baru yaitu meningkatkan kecemasan karena kurangnya pengetahuan dan belum adanya pengalaman pada ibu saat menghadapi persalinan sehingga produksi hormone adrenalin meningkat (Tuti Meihartati 2018).

Kecemasan menjelang persalinan pada kala 1, perasaan para ibu sering dirasakan ketakutan kematian ibu dan bayinya, ketakutan lahir cacat atau keadaan patologis, rasa bersalah dan berdosa berkaitan dengan

kehidupan emosi dan kasih sayang dari orang tuanya srta dosa-dosa masa lalu (Ysmael 2011). Untuk mengatasi kecemasan pada bumil dapat diterapkan intervensi non farmakologi dimana dapat mengontrol perasaannya. Menurut The Australian Assocition of Massage Therapists (AAMT. 2016) telah mendaftar beberapa metode dan massage (Koren 2017). terapi non farmakologis tanpa obat-obatan seperti relaksasi, massage, akupuntur, kompres hangat, masix, aroma terapi, Endorphin Massage merupakan salah satu cara untuk menghilangkan rasa lelah pada tubuh.

Endorphin Massage adalah sebuah terapi sentuhan atau pijatan ringan yang cukup penting diberikan pada ibu hamil hingga menjelang melahirkan, pijatan dapat melepaskan senyawa endorphin yang merupakan pereda rasa sakit yang dapat menatapkan rasa nyaman (Kuswandi 2014).

Tujuan penelitian ini adalah untuk mengetahui pengaruh endorphin masssage terhadap tingkat kecemasan pada ibu bersalin primigravida kala 1 di wilayah kerja puskesmas Tunggul Hitam kota Padang tahun 2019.

\section{METODE PENELITIAN}

Jenis penelitian ini menggunakan Quasi Eksperiment dengan rancangan two group pretest-PosttestDesign. Efektifitas perlakuan dinilai dengan cara membandikan nilai post test dan pre test. Penelitian ini dilaksanakan pada bulan Maret sampai November 2019 di Bidan Praktek Swata (BPS) yang ada di wilayah kerja Puskesmas Dadok Tunggul Hitam Kota Padang tahun 2019. Sampel dalam penelitian ini adalah ibu hamil yang berada pad kala 1 peralinan banyak 30 orang ,yang terbagi 15 intervensi dan 15 kontrol. Kriteria Inklusi peneitian ini adalah tidak mengalami komplikasi kehamilan, janin tunggal, dan kehamilan pertama (primigravida).Sementara kriteria enklusi penelitian adalah plasenta previa, multigravida, 
kehamilan dengan komplikasi dan ablasi.Pengambilan sampel penelitian dilakukan dengan teknik purposive sampling.Instrumen dalam penelitian yang digunakan alat endorphin untuk endorphine massage.

\section{HASIL DAN PEMBAHASAN}

\section{A. Karakteristik Responden}

Responden penelitian ibu-ibu primigravida yang berada pada kalai 1 . Sampel sebanyak 30 responden dengan pembagian 15 responden yang diberikan endorphine massage atau sebagai kelompok eksperimen, sedangkan 15 responden tidak diberikan endorphine massage atau sebagao kelompok kontrol. Distribusi frekuensi dan presentasi setiap variabel yang diperoleh berdasarkan penelitian yang dilakukan adalah:

Tabel 1. Data Distrubusi Karakteristik Responden Berdasarkan Umur pada Kelompok Eksperimen Dan Kontrol

\begin{tabular}{|c|c|c|c|c|}
\hline Umur & $\begin{array}{l}\text { Mea } \\
n\end{array}$ & SD & $\begin{array}{l}\text { Minim } \\
\text { al }\end{array}$ & $\begin{array}{l}\text { Maksi } \\
\text { mal }\end{array}$ \\
\hline $\begin{array}{l}\text { Eksperim } \\
\text { en }\end{array}$ & $\begin{array}{l}25.6 \\
7\end{array}$ & $\begin{array}{l}3.71 \\
6\end{array}$ & 19 & 31 \\
\hline Kontrol & $\begin{array}{l}25.9 \\
3\end{array}$ & $\begin{array}{l}3.57 \\
5\end{array}$ & 18 & 32 \\
\hline
\end{tabular}

Berdasarkan tabel 1 didapatkan ratarata umur responden pada kelompok eksperimen 25.67 tahun dengan standar deviasi 3.716 sedangkan rata-rata umur responden pada kelompok kontrol 25.93 tahun dengan standar deviasi 3.575. Umur ibu yang termuda 18 tahun dan umur ibu tertua 32 tahun.

Tabel 2. Data Distrubusi Karakteristik Responden Berdasarkan Pendidikan dan Pekerjaan Pada Kelompok Eksperimen Dan Kontrol

\begin{tabular}{llllll}
\hline \multirow{2}{*}{ Karakteristik } & \multicolumn{2}{c}{ Eksperimen } & \multicolumn{2}{c}{ Kontrol } \\
\cline { 2 - 6 } & & $\mathbf{F}$ & $\mathbf{\%}$ & $\mathbf{F}$ & $\mathbf{\%}$ \\
\hline Pendidikan & SMP & 1 & 6.67 & 2 & 13.33 \\
\cline { 2 - 6 } & SMA & 8 & 53.33 & 7 & 46.67 \\
\cline { 2 - 6 } & S1 & 4 & 26.67 & 6 & 40 \\
\cline { 2 - 6 } & S2 & 2 & 13.33 & 0 & 0 \\
\cline { 2 - 6 } & Total & $\mathbf{1 5}$ & $\mathbf{1 0 0}$ & $\mathbf{1 5}$ & $\mathbf{1 0 0}$ \\
\hline Pekerjaan & IRT & 7 & 46.67 & 6 & 40 \\
\cline { 2 - 6 } & PNS & 3 & 20 & 3 & 20 \\
\hline
\end{tabular}

\begin{tabular}{|c|c|c|c|c|}
\hline Swasta & 5 & 33.33 & 6 & 40 \\
\hline Total & 15 & 100 & 15 & 100 \\
\hline
\end{tabular}

Berdasarkan tabel 2 menunjukkan bahwa frekuensi pada jenjang pendidikan dan pekerjaan ibu primigravida yang mengalami kecemasan, pada kelompok eksperimen didapatkan $8(53,33 \%)$ responden dan pada kelompok kontrol didapatkan 7 (46.67\%) yang berpendidikan SMA. Sedangkan distribusi ibu primigravida yang mengalami kecemasan pada kelompok eksperimen didapatkan 7 (46.67\%) dan pada kelompok kontrol $6(40 \%)$ yang mempunyai pekerjaan sebaga IRT (ibu rumah tangga).

B. Pengaruh Endorphine Massage terhadap Tingkat Kecemasan Ibu Primigravida Kala 1 di wilayah Kerja Puskesmas Dadok Tunggul Hitam Kota Padang.

Tabel 3. PengaruhEndorphine Massage terhadap Tingkat Kecemasan Ibu primigravida Kala 1 di wilayah Kerja Puskesmas Dadok Tunggul Hitam Kota Padang tahun 2019

\begin{tabular}{|c|c|c|c|c|c|c|}
\hline \multirow[t]{2}{*}{ Kelompok } & \multirow[t]{2}{*}{$\mathbf{N}$} & \multirow[t]{2}{*}{ Mean } & \multirow[t]{2}{*}{ SD } & \multicolumn{2}{|c|}{$\begin{array}{l}95 \% \\
\text { confidence }\end{array}$} & \multirow[t]{2}{*}{$\begin{array}{l}\text { Sig. (2- } \\
\text { tailed) }\end{array}$} \\
\hline & & & & Lower & Upper & \\
\hline $\begin{array}{l}\text { Sebelum dan } \\
\text { sesudah } \\
\text { kelompok } \\
\text { Eksperimen }\end{array}$ & 15 & 0,667 & 0,724 & 0,266 & 1.067 & 0.003 \\
\hline $\begin{array}{ll}\text { Sebelum dan } \\
\text { Sesudah } \\
\text { Kelompok } \\
\text { Kontrol }\end{array}$ & 15 & 0,267 & 0,458 & 0,013 & 0,520 & 0.041 \\
\hline
\end{tabular}

Berdasarkan tabel 3 menunjukkan bahwa nilai rata-rata tingkat kecemasan pada kelompok eksperimen adalah 0,667, sedangkan rata-rata tingkat kecemasan pada kelompok kontrol adalah 0,267. Hasil ini menyatakan bahwa rata-rata tingkat kecemasan pada kelompok eksperimen lebih tinggi dibandingkan dengan rata-rata tingkat kecemasan pada kelompok kontrol.

Peneliti melakukan uji normalitas tingkat kecemasan pada kelompok eksperimen pada data sebelum memperoleh nilai $p=0,200(\mathrm{p}>0,05)$ serta uji normalitas pada data sesudah dan memperoleh nilai $\mathrm{p}=0,452(\mathrm{p}>0,05)$. Berdasarkan nilai $\mathrm{p}$ yang diperoleh menunjukkan data berdistribusi normal karena nilai p lebih dari $0,05(\mathrm{p}>0,05)$ sehingga memenuhi syarat untuk dilakukan 
uji paired sampel T-test. Berdasarkan uji ttest yang telah dilakukan diperoleh nilai signifikan $\mathrm{p}$ value $0,003(\mathrm{p}<0,05)$ sehingga hipotesis dalam penelitian ini diterima. Artinya terdapat tingkat kecemasan yang bermakna pada kelompok eksperimen sebelum dan sesudah diberi massage endorphine.

Peneliti melakukan uji normalitas tingkat kecemasan pada kelompok kontrol data sebelum memperoleh nilai $p=0,200$ $(p>0,05)$ serta uji normalitas pada data sesudah dan memperoleh nilai $\mathrm{p}=0,730$ $(p>0,05)$. Berdasarkan nilai $p$ yang diperoleh menunjukkan data berdistribusi normal karena nilai $p$ lebih dari $0,05 \quad(p>0,05)$ sehingga memenuhi syarat untuk dilakukan uji paired sampel T-test. Berdasarkan uji ttest yang telah dilakukan diperoleh nilai signifikan $p$ value $0,041(p<0,05)$ sehingga hipotesis dalam penelitian ini diterima. Artinya terdapat tingkat kecemasan yang bermakna pada kelompok kontrol sebelum dan sesudah tanpa diberi endorphine massage.

Penelitian ini sama dengan penelitian yang dilakukan oleh Rama (2017) menunjukkan bahwa ada pengaruh endorphine massage terhadap tingkat kecemasan pada ibu primigravida usia kehamilan > 36 minggu dengan dengan nilai $\mathrm{p}$ value $0,000(<0,05)$. Hal ini sejalan dengan penelitian yang dilakukan Tuti (2018) bahwa ada efektivitas endorphine massage terhadap tingkat kecemasan ibu bersalin primipara kala 1 fase aktif di Rumah sakit Ibu dan anak paradise.

Berdasarkan hal ini adanya perubahan tingkat kecemasan setelah diberikan endorphine massage. Tingkat kecemasan ibu primigravida pada kala 1 sebagian besar berasa pada tingkat kecemasan berat. Setelah pemberian endorphine massage terjadi penurunan tingkat kecemasan. Hal ini sesuai dengan manfaat dari endorphine massage yakni mengatasi kecemasan dan mengurangi nyeri waktu persalinan dengan cara penatalaksanaan non farmakologi. Endorphine massage merupakan terapi sentuhan/ pijatan ringan yang diberikan kepada ibu hamil dan saatnya melahirkan. Teknik endorphine massage membantu memberikan rasa tenang dan nyaman baik disaat mendekati persalinan maupun proses persalinan akan berlangsung.Endorphine merupakn sebuah zat didalam tubuh yang memiliki sekali manfaat dari gabungan endogenous dan morphine dimana zat yang merupakan unsur protein yang diproduksi oleh sel-sel tubuh serta saraf manusia. Hai ini menyebabkan sentuhan massage dapat merangsang tubuh untuk melepasakan senyawa endorphine yang merupakan pereda rasa sakit dan memberikan rasa nyaman (Aprillia 2011).

Hal ini sejalan dengan penelitian yang dilakukan Sukmaningtyas and Windiarti n.d (2017) bahwa teknik massage membantu ibu hamil merasa nyaman, rileks, dam lebih segar selama proses persalinan. Pada penelitian ini peneliti menggunakan alat pijat yang diberi nama endorphin, dimana alat ini sangat membantu dalam hal memberi massage/ pijatan. Karena pijatan dapat merangsang tubuh untuk melepaskan endorphin yang menormalkan denyut jantung dan mengurangi rasa sakit, mengendalikan perasaaan stress dan menciptakan perasaan nyaman dan merileks kondisi tubuh dengan memicu perasaan nyaman melalui permukaan kulit (Rahayu, Widyawati, and Dewi 2018).

Dengan penelitian ini dapat disimpulkan bahwa endorphine massage sangat berpengaruh untuk menurunkan tingkat kecemasan ibu primigravida kala 1 dalam menghadapi persalinan. Teknik endorphine massage juga dapat mengontrol diri individu ketika rasa ketidaknyamanan atau cemas, emosi labil yang disebabkan kecemasan.Endorphin massagedapat mengurangi kecemasan, ketegangan dan ketidaknyamanan yang dialami ibu bersalin akan dapat berkurang karena sentuhan atau endorphin massage memberi pengaruh positif terhadap kesejahteraan fisik dan psikis ibu.

\section{SIMPULAN}

Kesimpulan dalam penelitian ini memperoleh nilai rata-rata tingkat kecemasan pada kelompok eksperimen adalah 0,667, sedangkan rata-rata tingkat kecemasan pada kelompok kontrol adalah 0,267.Uji normalitas tingkat kecemasan pada kelompok eksperimen pada data sebelum memperoleh nilai $p=0,200$ 
( $>>0,05)$ serta uji normalitas pada data sesudah dan memperoleh nilai $\mathrm{p}=0,452 \quad(\mathrm{p}>0,05)$. Berdasarkan nilai $\mathrm{p}$ yang diperoleh menunjukkan data berdistribusi normal karena nilai $\mathrm{p}$ lebih dari $0,05 \quad(\mathrm{p}>0,05)$ sehingga memenuhi syarat untuk dilakukan uji paired sampel T-test. Berdasarkan uji t-test yang telah dilakukan diperoleh nilai signifikan $\mathrm{p}$ value $0,003 \quad(\mathrm{p}<0,05)$ sehingga hipotesis dalam penelitian ini diterima. Artinya terdapat tingkat kecemasan yang bermakna pada kelompok eksperimen sebelum dan sesudah diberi massage endorphine. Berdasarkan uji t-test yang telah dilakukan diperoleh nilai signifikan $\mathrm{p}$ value $0,041 \quad(p<0,05) \quad$ sehingga hipotesis dalam penelitian ini diterima. Artinya terdapat tingkat kecemasan yang bermakna pada kelompok kontrol sebelum dan sesudah tanpa diberi endorphine massage.

\section{UCAPAN TERIMAKASIH}

Ucapan terima kasih peneliti sampaikan kepada Kemeristekdikti yang telah memberikan kesempatan dalam penelitian dosen pemula (PDP), Yayasan dan Ketua STIKes Alifah Padang yang telah memberikan motivasi dan menfasilitasi peneliti untuk melakukan penelitian. Pimpinan puskesmas Dadok tunggul Hitam padang telah memberikan izin dalam melaksankan penelitian dan responden yang telah berpartisipasi dalam penelitian ini, serta teman sejawat yang telah mendukung peneliti dalam menyelesaikan laporan penelitian ini.

\section{DAFTAR PUSTAKA}

AAMT. 2016. Australian Association of Massage Therapists.

Aprillia, Yesie. 2011. Siapa Bilang Melahirkan Itu Sakit. Yogyakarta: Andi Offset.

Biaggi A. C. P. P. 2015. "Identifying the Women at Risk of Antenatal Anxiety and Depression a Systematic Review." J affect Disord.

Departemen Kesehatan RI. 2015. Profil Kesehatan Indonesia. Jakarta: Departemen Kesehatan RI.

Göbel, Ariane et al. 2018. "The Association between Maternal-Fetal Bonding and Prenatal Anxiety: An Explanatory Analysis and Systematic Review." Journal of Affective Disorders 239: 313-27.

Koren, K. 2017. "Deep Tissue Massage: What Are Talking About?" Journal of Bodywork \& Movement Therapies.

Kuswandi, L. 2014. Hynobirting a Gentle Way to Give Birth. Jakarta: Pustaka Bunda.

Rahayu, Sri, Melyana Nurul Widyawati, and Retno Kusuma Dewi. 2018. "Pengaruh Masase Endorphin Terhadap Tingkat Kecemasan Dan Involusio Uteri Ibu Nifas." Jurnal Kebidanan 8(1): 29-36.

Sukmaningtyas, Wilis, and Prahesti Anita Windiarti. "Efektivitas Endorphine Massage Terhadap Tingkat Pendahuluan Masalah Kehamilan Dan Persalinan Merupakan Fokus Perhatian Yang Sangat Penting Dalam Kehidupan Masyarakat . Pada Proses Persalinan Terjadi Sebuah Kombinasi Antara Proses Fisik Dan Pengalaman Emos." : 53-62.

Tuti Meihartati, Siti Mariana. 2018. "Efektivitas Endorphin Massage Terhadap Tingkat Kecemasan Ibu Bersalin Primipara Kala 1 Fase Aktif (The Effectiveness Of Endorphin Massage To Maternal Anxiety Level Who Primipara Active Phase I)." Jurnal Darul Azhar 5(1): 85-93.

WHO. 2014. "World Health Statistic."

Wiknjosastro, H. 2010. Ilmu Kebidanan. Jakarta: Yayasan Bina Pustaka Sarwono Prawirohardjo.

Ysmael, F.E.B. 2011. "Music on Thesecond Stage of Labor Among Women in the First Pregnancy. Cebu Normal University." Cebu Normal University. Internasional Peer Reviwed. Journal.

Zumrut, y.S. 2018. "The Effect of Foot Reflexology on the Anxiety Levels of Women in Labor." The Journal of Alternative and Complementary Medicine. 